\title{
Sex differentiation in the histology of the digestive gland of Nephrops norvegicus from Pagasitikos Gulf during spring
}

\author{
Eleni Stathopoulou, Chrisoula Apostologamvrou, Dimitris Vafidis, Eleni Mente and Panagiotis Berillis \\ Department of Ichthyology and Aquatic Environment, School of Agricultural Sciences, University of Thessaly, Fytoko Street, \\ 38446 N. Ionia Magnisias, Greece
}

Received 22 January 2017 / Accepted 9 June 2017

Handling Editor: George Katselis

\begin{abstract}
The aim of this research is to study the seasonal histological changes in the digestive gland of males and females Nephrops norvegicus at the Pagasitikos Gulf. The food availability in Pagasitikos Gulf varies and depends on the seasonality, physicochemical conditions and diversification of organic material. After obtaining histological sections, the size of tubules, their lumens and the R-, F- and B-cells were calculated in March and May. A special image analysis algorithm was used that can automatically calculate both the above area ratios using digestive gland histological sections. Both male and female, which were sampled in May, had a larger density of lipid droplets than N. norvegicus sampled in March. However, females sampled in May had more lipid droplets per tubule and a smaller F-cell-to-tubule ratio than males, which indicated that the intensive feeding period had started for reproduction in the females. The digestive gland can be used as a nutritional indicator to assess the nutritional status of Nephrops stocks and to assist with the management of the Nephrops wild stocks by proposing a seasonal fishery management plan to improve the sustainability of the stocks.
\end{abstract}

Keywords: Nephrops norvegicus / Digestive gland / R-cells / B-cells / F-cells

\section{Introduction}

The Norway lobster, Nephrops norvegicus (Linnaeus 1758), is one of the most commercially important crustacean species in Europe, with the number of total catches over the last decade reaching a plateau or even declining (Smith and Papadopoulou, 2008; Ungfors et al., 2013). This species can be found in fine sediments between 20 and $800 \mathrm{~m}$ in depth. $N$. norvegicus may be considered primarily carnivorous. Their diet is mainly composed of bivalve molluses, polychaetes, echinoderms, fish, and crustaceans, including conspecifics (Welden et al., 2015). Its biology, fisheries and management have been studied extensively, with many studies investigating its reproduction, larval stages and population biology (Sarda, 1995; Rotllant et al., 2001, 2004; dos Santos and Peliz, 2005; Bell et al., 2006), ecology and nutritional physiology (Yonge, 1924; Stentiford et al., 2001; Ridgway et al., 2006; Mente, 2010; Mente et al., 2009, 2011; Watts et al., 2014). However, little is known about its organ-specific morphology, such as the hepatopancreas, in response to food availability. The hepatopancreas, also known as the digestive gland or midgut gland, can be used as a

\footnotetext{
${ }^{*}$ Corresponding author: pveril@uth.gr
}

nutritional indicator similar to whole body weight because there is a functional prioritization of this organ in the response of Nephrops to food availability and deprivation.

The digestive gland, or hepatopancreas, is considered an important organ in crustacean decapods because it is responsible for various metabolic activities (Gibson and Barker, 1979). It is responsible for the synthesis and secretion of digestive enzymes and the final digestion of food. It also contributes to the storage of lipids and carbohydrates (Barker and Gibson, 1977; Gibson and Barker, 1979; Factor, 1995; Watts et al., 2014). In N. norvegicus, the hepatopancreas accounts for an average of $6 \%$ of the whole body weight and, when used as a storage site of lipids (representing an approximately $30 \%$ of the hepatopancreas in terms of weight), can be a source of exploitable internal reserves when food is limited or absent (Watts et al., 2014). Nephrops can survive periods of extended nutritional stress such as long periods without food, even for up to six months, by lowering their metabolic rate and by using hepatopancreatic lipids and other internal reserves in response to food deprivation (Dall, 1981; Baden et al., 1994; Mente et al., 2011; Watts et al., 2014). The digestive gland consists of too many microtubules (glands), each of which has a double network of longitudinal and circular muscles that contract and expand. Microtubules have a diameter of a few hundred micrometres and vary in length 


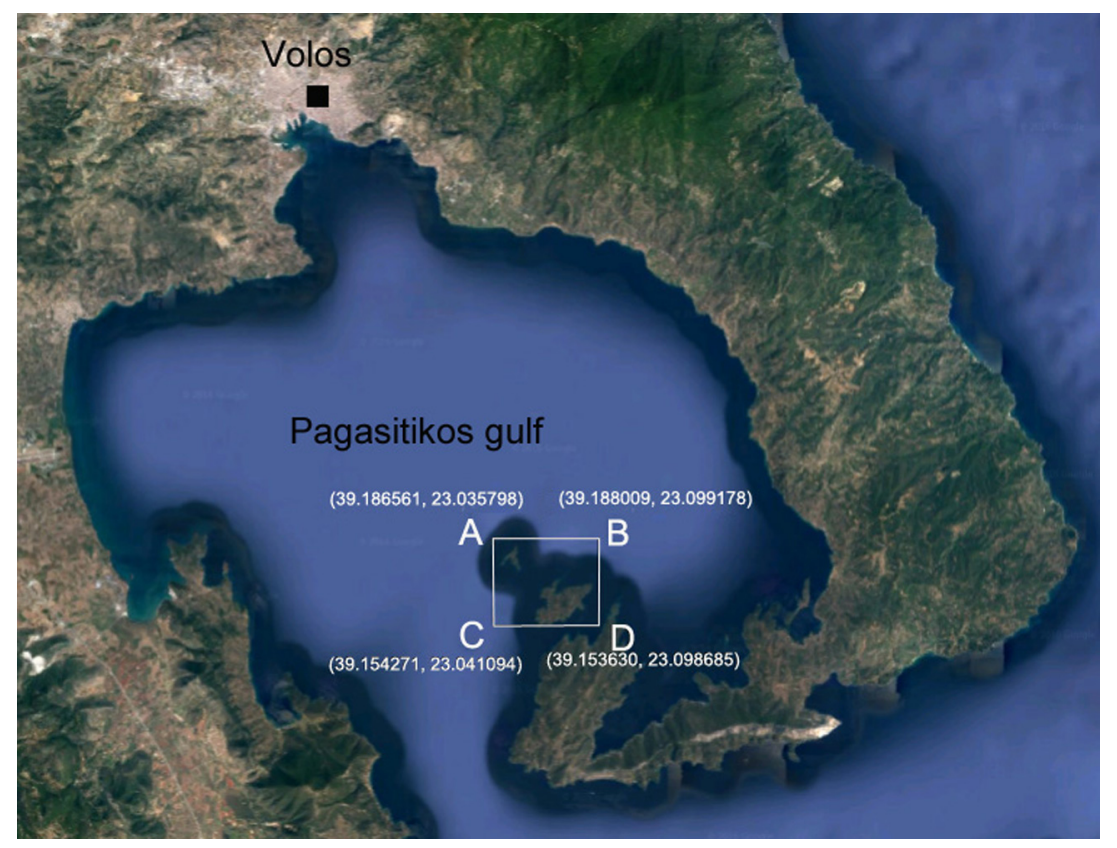

Fig. 1. Pagasitikos gulf. Sampling area was the rectangular ABCD.

(Factor, 1995). Tubules are composed of discrete regions, top area, middle area and the proximal area, and each region has a different functional purpose (Conklin, 1995). The digestive gland epithelium comprises five cell types: embryonic cells (Ecells), resorptive cells (R-cells), fibrillar cells (F-cells), blisterlike cells (B-cells) and micro cells (M-cells) (Hirsch and Jacobs, 1930; Barker and Gibson, 1977). The relationship and exact function of these five cell types in crustaceans are controversial and may vary depending on the species. However, according to a study of the European lobster (Barker and Gibson, 1977), the most likely scenario is that the E-cells produce both $\mathrm{R}$ and $\mathrm{F}$ cells and that F-cells subsequently mature into B-cells (Gibson, 1983; Factor, 1995).

Changes in the structure of the digestive gland are related to absorption capacity and disturbances in stored nutrients since it responds rapidly to food deprivation and moulting. Changes can also occur in cases of poor nutrition or starvation (Simon, 2009; Berillis et al., 2013, Rotllant et al., 2014). Determining the hepatosomatic index (HSI) and conducting a histological study of the digestive gland can be used as indicators for assessing the nutritional status of crustaceans that will be based on the available food quality and quantity. The quality and quantity of the available food are critical factors for maintaining the crustaceans stock at the desired levels. The morphology of the digestive gland can be used as a nutritional indicator in that way. The Pagasitikos Gulf is a meso-oligotrophic system (Kormas et al., 2014) and a rather sensitive ecosystem due to its semienclosed nature and shallow depths. Changes in food availability in the benthos of the Pagasitikos Gulf vary depending on the seasonality, stable physicochemical conditions (temperature, light, salinity) and diversification of organic material (Petihakis et al., 2005). Starting at the annual bloom, which occurs from January to February, the maximum amount of high nutritional value organic material ends in the sediment at the end of February or early March. Finally, the highest food availability in benthos is observed in April and May (Petihakis et al., 2005).
The purpose of this research is to determine whether there are any sexual morphological differences in the $N$. norvegicus digestive gland in the first and last months of spring, when there are changes in the benthic food availability in Pagasitikos gulf, in Greece. The ratios of lumen, B-cells, F-cells and Rcells to the whole tubule areas were calculated for both male and female individuals. A specific image analysis algorithm was used. It can automatically calculate the above ratios by using micrographs of digestive gland histological sections (Berillis et al., 2013). The specific image analysis algorithm to analyze Nephrops nutritional condition has application in the established Nephrops fishery since it evaluates its' quality and assist with the local management of the wild stocks.

\section{Material and methods}

A total of $57 \mathrm{~N}$. norvegicus individuals were collected in March and May 2016 by a commercial fishing boat using creels $(60 \mathrm{~cm} \times 45 \mathrm{~cm} \times 30 \mathrm{~cm}$, length $\times$ width $\times$ height, 28 $\mathrm{mm}$ mesh size) operating at a depth of $80-90 \mathrm{~m}$ in the Pagasitikos Gulf (Greece) (Fig. 1). Thirty of them were males, and the other 27 were females. Specifically, in March, 16 male and 12 female individuals were caught, and in May, 14 males and 15 females were caught. The creels were collected one day after their placement in the sampling area at the March sampling and two days after their placement at the May sampling. In most cases, there were 1 or $2 N$. norvegicus in the creels. The baits used in the traps were Sardinella aurita.

Live individuals were transferred to the laboratory into a tank filled with seawater. The total length and weight were measured. Digestive glands were removed and weighed, and the HSI was calculated. A piece of tissue, approximately $0.5-1 \mathrm{~cm}$, of each individual digestive gland was placed in a bottle containing a solution of $4 \%$ formaldehyde in sterilized seawater and stored in a refrigerator $\left(4^{\circ} \mathrm{C}\right)$. 

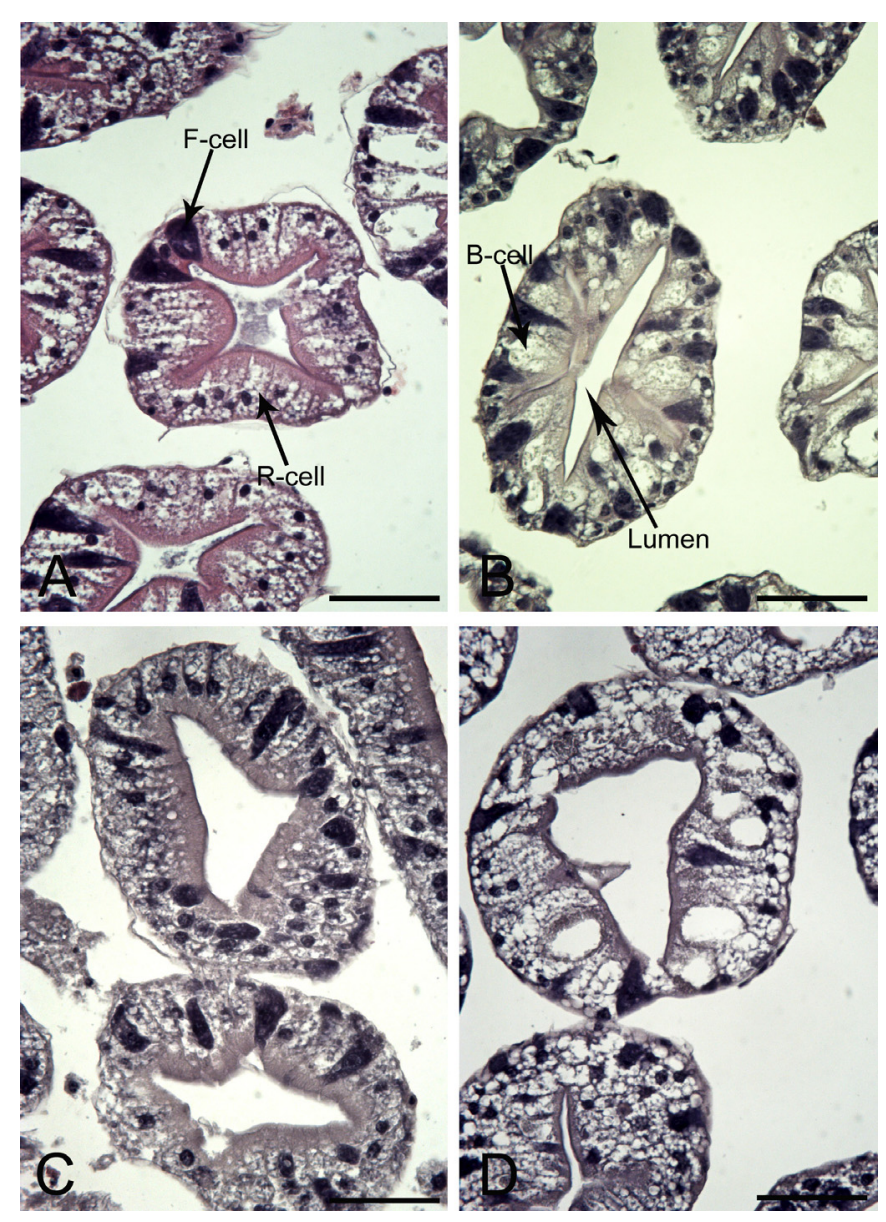

Fig. 2. (A, B) March sampling. Digestive glands tubule from male (A) and female (B) N. norvegicus. (C, D) May sampling. Digestive glands tubule from male (A) and female (B) N. norvegicus. Scale bar $=5.5 \mu \mathrm{m}$.

For light microscopy, samples were first fixed in $4 \%$ buffered formalin in sterilized seawater for $24 \mathrm{~h}$ at $4{ }^{\circ} \mathrm{C}$ and then immediately dehydrated in a graded series of ethanol, immersed in xylol, and embedded in paraffin wax. Sections of 5-7 $\mu \mathrm{m}$ were mounted. After deparaffinization, the sections were rehydrated, stained with haematoxylin and eosin, and mounted with Cristal/Mount. The sections of the histological preparations were studied by light microscopy (Bresser Science TRM 301) under a total magnification of $100 \times$ and $400 \times$. A digital camera affixed to the microscope (Bresser MikroCam 5.0 MP) was used to acquire histological micrographs (Fig. 2). Micrographs were analyzed using special software (Berillis et al., 2013). Digital images of random cross sections of the digestive gland tubules were selected to measure the surface area of the whole tubule, tubule lumen, and R-, B- and F-cells in each tubule. The ratios of lumen area to whole tubule area and total cell area to whole tubule area were calculated so a direct comparison between individual $N$. norvegicus samples could be performed. The ratios were also more accurate than were the absolute measurements because they eliminated the potential differences in area due to the small changes in the sectioning angle in relation to tubules. The

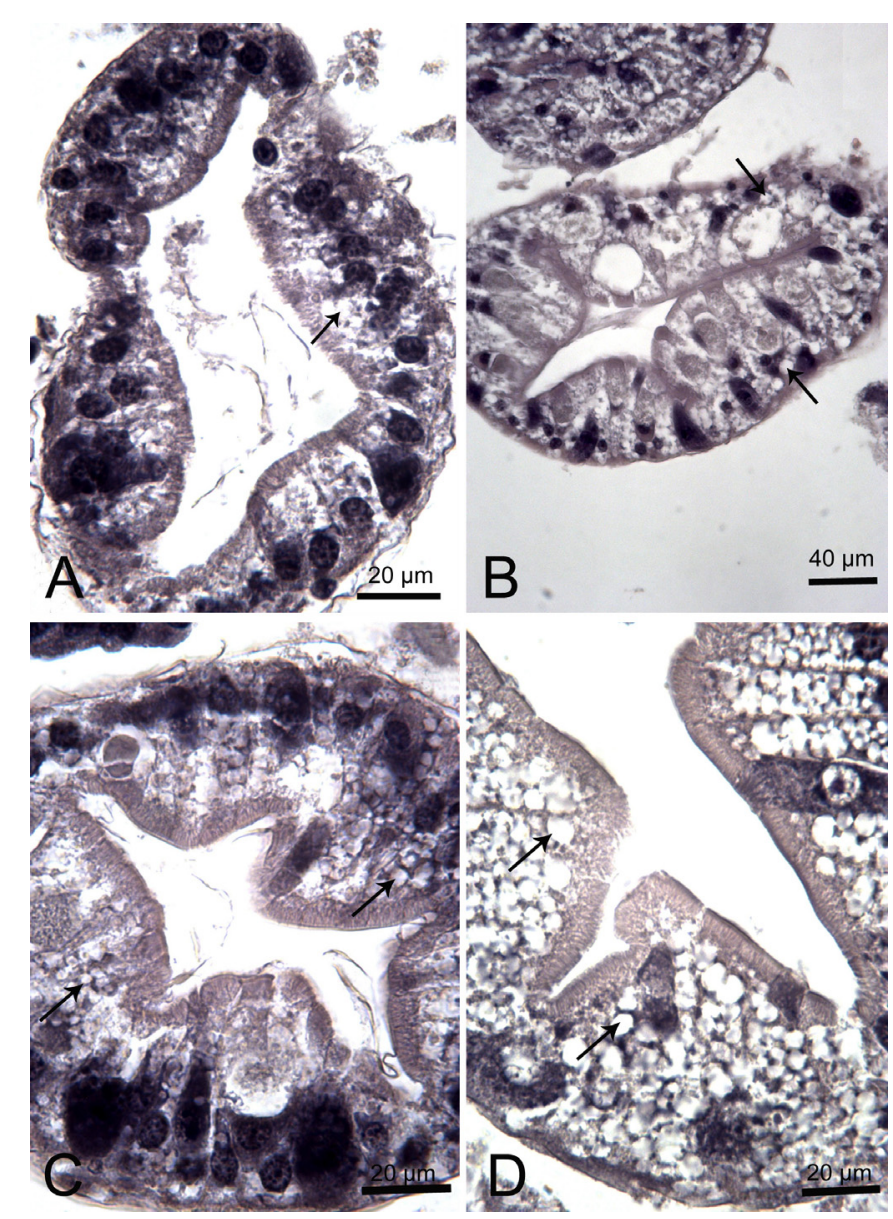

Fig. 3. High magnification images from $N$. norvegicus digestive gland for lipid droplets density determination. (A) March sampling. Digestive glands tubule from male with a very low density of lipid droplets (arrow). It was scored as 1 at the semi-quantitative scoring system. (B) May sampling. Digestive glands tubule from female with a low-moderate density of lipid droplets (arrow). It was scored as 2 at the semi-quantitative scoring system. (C) May sampling. Digestive glands tubule from male with a moderate-high density of lipid droplets (arrow). It was scored as 3 at the semi-quantitative scoring system. (D) May sampling. Digestive glands tubule from female with a high-very high density of lipid droplets (arrow). It was scored as 4 at the semi-quantitative scoring system.

number of B- and F-cells per tubule was measured for male and female individuals of both sampling periods. To estimate the amount of lipid droplets per tubule, a semi-quantitative scoring system was used. The amount of the lipid droplets was scored on a scale from 1 to 4 . A higher score represented a larger amount of lipid droplets per tubule (Fig. 3).

All values of surface areas of histological section of the hepatopancreatic tubule were presented as means with standard error of mean in parenthesis. Statistical differences that were present at 5\% level were considered significant (Zar, 1996). The values were checked for normality using the Shapiro-Wilk test. Statistical comparisons between the distributions of variables that did not show a normal distribution are made using the MannWhitney test (Zar, 1996). 
Table 1. Body weight, total body length, carapace length and HIS of the N. norvegicus for comparison between months and sex, with number of samples in parenthesis. Results are given as means with standard error of mean within parenthesis. Means in a column per month and per sex followed by the same superscript are not significantly different $(p>0.05)$.

\begin{tabular}{|c|c|c|c|c|c|}
\hline \multicolumn{2}{|c|}{ N. norvegicus } & $\frac{\text { Body weight }(\mathrm{g})}{55.46^{\mathrm{a}}(3.46)}$ & $\frac{\text { Total body length }(\mathrm{mm})}{126.40^{\mathrm{a}}(2.76)}$ & $\begin{array}{l}\text { Carapace length }(\mathrm{mm}) \\
57.7^{\mathrm{a}}(5.2)\end{array}$ & $\frac{\text { HSI }}{2.97^{\mathrm{a}}(0.22)}$ \\
\hline March & Female (12) & $40.56^{\mathrm{b}}(1.57)$ & $112.10^{\mathrm{b}}(6.28)$ & $51.2^{\mathrm{b}}(3.9)$ & $2.91^{\mathrm{a}}(0.16)$ \\
\hline \multirow[b]{2}{*}{ May } & Male (14) & $58.74^{\mathrm{a}}(4.40)$ & $135.45^{\mathrm{a}}(3.41)$ & $58.0^{\mathrm{a}}(6.8)$ & $2.50^{\mathrm{a}}(0.1)$ \\
\hline & Female (15) & $40.65^{\mathrm{b}}(1.94)$ & $123.09^{\mathrm{a}, \mathrm{b}}(7.94)$ & $50.0^{\mathrm{b}, \mathrm{c}}(4.9)$ & $2.46^{\mathrm{a}}(0.24)$ \\
\hline
\end{tabular}

Table 2. Digestive gland ratios of structural elements of $N$. norvegicus compared between months and sex, with number of the measured tubules in brackets. Results are given as means with standard error of mean within parenthesis. Means in a column per month and per sex followed by the same superscript are not significantly different $(p>0.05)$.

\begin{tabular}{|c|c|c|c|c|c|}
\hline & egicus & $\begin{array}{l}\text { Lumen to whole } \\
\text { tubule area ratio }\end{array}$ & $\begin{array}{l}\text { B-cells to whole } \\
\text { tubule area ratio }\end{array}$ & $\begin{array}{l}\text { F-cells to whole } \\
\text { tubule area ratio }\end{array}$ & $\begin{array}{l}\text { R-cells to whole } \\
\text { tubule area ratio }\end{array}$ \\
\hline March & Male (160) & $0.12^{\mathrm{a}}(0.007)$ & $0.10^{\mathrm{a}}(0.006)$ & $0.09^{\mathrm{a}}(0.004)$ & $0.80^{\mathrm{a}}(0.009)$ \\
\hline \multirow{2}{*}{ May } & Male (140) & $0.14^{\mathrm{b}}(0.005)$ & $0.09^{\mathrm{a}} \pm(0.005)$ & $0.09^{\mathrm{a}}(0.003)$ & $0.82^{\mathrm{a}}(0.006)$ \\
\hline & Female (150) & $0.13^{\mathrm{a}, \mathrm{b}}(0.007)$ & $0.10^{\mathrm{a}}(0.007)$ & $0.08^{\mathrm{b}}(0.003)$ & $0.82^{\mathrm{a}}(0.007)$ \\
\hline
\end{tabular}

Table 3. Number of B-cells, F-cells per tubule and estimation of lipid droplets amount per tubule from the digestive gland of N. norvegicus compared between months and sex, with number of the measured tubules in brackets. Results are given as means with standard error of mean within parenthesis. Means in a column followed by the same superscript are not significantly different $(p>0.05)$.

\begin{tabular}{lllll}
\hline & $N$. norvegicus & $\begin{array}{l}\text { Number of B-cells } \\
\text { per tubule }\end{array}$ & $\begin{array}{l}\text { Number of F-cells } \\
\text { per tubule }\end{array}$ & $\begin{array}{l}\text { Estimation of lipid droplets } \\
\text { amount per tubule }\end{array}$ \\
\hline \multirow{3}{*}{ March } & Male (50) & $5.16^{\mathrm{a}, \mathrm{b}}(0.66)$ & $5.47^{\mathrm{a}}(0.28)$ & $2.87^{\mathrm{a}}(0.13)$ \\
& Female (50) & $5.67^{\mathrm{b}}(0.68)$ & $4.79^{\mathrm{b}}(0.35)$ & $3.00^{\mathrm{a}}(0.13)$ \\
May & & & & $3.42^{\mathrm{b}}(0.06)$ \\
& Male (50) & $3.51^{\mathrm{c}, \mathrm{a}}(0.49)$ & $5.10^{\mathrm{a}, \mathrm{b}}(0.28)$ & $3.64^{\mathrm{c}}(0.06)$ \\
\hline
\end{tabular}

\section{Results}

Body weight, total body length, carapace length and HIS of the $N$. norvegicus are shown in Table 1 . The body weight of the March caught $N$. norvegicus samples was $55.46 \mathrm{~g}$ (3.46) for the males and 40.56g (1.57) for the females, while the total body length and the HSI was $126.40 \mathrm{~mm}$ (2.76) for the males and $112.10 \mathrm{~mm}(6.28)$ for the females and $2.97(0.22)$ for the males and $2.91(0.16)$ for the females, respectively. The females were statistically significant smaller in terms of body weight, total length and carapace length than the males in both sampling months $(p<0.05)$ (Table 1). There were no statistical significant differences between the HSI for both sexes and sampling periods $(p>0.05)$ (Table 1$)$.

Ratios of structural elements from digestive gland of the $N$. norvegicus are shown in Table 2 . The R-cell to whole tubule ratio was not statistically different between months and sexes (Table 2). Lumen to whole tubule area ratio from males sampled on May showed higher statistically significant difference $(p<0.05)$ than females and males from the March and May sampling (Table 2).

The B-cell-to-tubule area ratios did not differ statistically among months and sexes $(p>0.05)$ (Table 2). Nevertheless, the number of B-cells per tubule was significant lower $(p<0.05)$ in females sampled on May in comparison with females sampled on March (Table 3). In addition, the number of B-cells per tubule for males sampled on March and May were similar $(p>0.05)$.

The number of F-cells to whole tubule area ratio were statistical significant lower at females sampled on May in comparison to males sampled on May and both sexes sampled on March $(p<0.05)$ (Table 2). Furthermore, females sampled on March and May had significant lower numbers of F-cells per tubule $(p<0.05)$ than the males sampled on March and May, respectively (Table 3).

From a visual assessment, R-cells of $N$. norvegicus of the May sampling (both males and females) had a larger density $(p<0.05)$ of lipid droplets than N. norvegicus from the March 
sampling. Females sampled on May appear to have a bigger amount $(p<0.05)$ of lipid droplets per tubule than the males ones sampled the same month. For the March sampling the lipid droplet amount per tubule was similar for both males and females (Table 3).

\section{Discussion}

Nephrops support one of the most valuable commercial wild fisheries in Greece (Smith et al., 2003; Smith and Papadopoulou, 2008). Demand for Nephrops is increasing at a time when Nephrops fisheries production remains stable and environmental conditions and food availability can affect its growth and nutritional condition. A technique to analyze Nephrops nutritional condition has a potential to assist with the management of local wild stocks to keep them at the desired levels. The morphology of the digestive gland can be used as a nutritional indicator and the specific image analysis algorithm tool evaluated in this study can assist in selecting the appropriate month for harvesting in relation to the species nutritional profile.

Pagasitikos Gulf, in Greece, is an area of high interest for $N$. norvegicus fishing ground as this is the shallowest occurrence ( $<100 \mathrm{~m}$ depth) of the species in high quantities in Greek waters (Smith and Papadopoulou, 2008). It has a muddy sediment in relatively shallow waters, a constant cold bottom water temperature and is undisturbed by trawling allowing full development of sedimentary burrowing communities of Nephrops (Smith et al., 2003). Nephrops landings in Pagasitikos gulf are $30 \mathrm{t}$ representing a $10 \%$ of the Greek total production (Hellenic Statistical Authority (HELSTAT); Moutopoulos and Stergiou, 2012). Pagasitikos gulf is an area closed to bottom trawling since 1966 (regulation BD 817 15/ $10 / 1966$ ) as a conservation measure. However, bottom nets and baited creels is allowed on the bottom except seasonal closures (regulation FEK 126 9/07/2004) for 3 months in the summer for the bottom nets and from 1st of May to 31 st of July for the baited creels together with the $28 \mathrm{~mm}$ minimum square mesh sizes for the creels (Mente et al., 2009). April to August is the time of female Nephrops maximum availability on the sediment surface (Smith et al., 2003). According to the models constructed by Petihakis (2005), the sediment surface of the central-external area at a depth $<50 \mathrm{~m}$ is characterized by consistently low temperatures (annual mean of $13-14^{\circ} \mathrm{C}$ ) and dim light conditions. Each year between January and February, there is a phytoplankton bloom in which the phytoplankton biomass reaches its maximum level in the sediment shortly after the bloom initiation (Petihakis et al., 2005). The maximum detritus concentrations reach the sediment surface during February and March, but after April, a decrease is observed in the phytoplankton, detritus and bacterial biomass (Petihakis et al., 2005). These patterns have positively affected the benthic food web by increasing the activity of suspension and depositing feeders shortly after the peaks of phytoplankton, bacteria and detritus around April or May. Thus, the above is explaining why months March and May were chosen for this study since are the first and last months of spring, when there are changes in the benthic food availability in Pagasitikos gulf. Furthermore, spawning (egg laying on the pleopods) in the Mediterranean Sea in Nephrops populations occurs in late summer to early autumn, and the eggs hatch in winter (Smith and Papadopoulou, 2008). Mediterranean larvae are adapted for early post-hatching survival under food-limited conditions, which occurs in an oligotrophic environment, by having a significantly higher wet mass and protein levels (Rotllant et al., 2004). In Pagasitikos Gulf, the proportion of females with a fully mature ovary increased from January to the summer months, with a peak in June and remained above $48 \%$ until October followed by a decline until December (Mente et al., 2009). In March $35 \%$ of the females appeared to have a fully mature ovary, whereas in May, this percentage had increased to $65 \%$ (Mente et al., 2009).

Reproduction and nutrition of Nephrops have been studied in Pagasitikos gulf to examine their stocks. For decapod crustaceans, the relative size of the HSI is an indicator of their nutritional status (Jones and Obst, 2000). Rotllant et al. (2014) found that wild $N$. norvegicus caught from the Pagasitikos Gulf had a mean value of 3.9 HSI index, whereas the $N$. norvegicus kept in captivity and fed with mussels and pellets had lower HSI indices (mean value of 2.0 for the mussel and 1.9 for the pellet fed dietary treatments). Starved $N$. norvegicus from Rotllant et al. (2014) had a mean value of 1.4 HSI index. Our results showed that the HSI values for the wild Nephrops ranged between $2.97(0.22)$ and $2.46(0.24)$, thus they were not starved. There was no significant difference in the HSI between males and females, which indicated that in general, male and female $N$. norvegicus were in similar nutritional conditions. Our values are larger than those reported by Rotllant et al. (2014) for $N$. norvegicus in captivity and starvation and are smaller than the corresponding values reported for the wild individuals. The difference between the HSI of the wild individuals reported by Rotllant et al. (2014) and our results might indicate that the Pagasitikos Gulf is a sensitive ecosystem with high intra- and inter-annual variability in its food availability between seasons and years.

During the summer period, female $N$. norvegicus have intense feeding activity (Froglia and Gramitto, 1979). Little is known about the feeding behaviour of females during their breeding period because they spend an increased amount of time in their burrows and cannot be caught by fishermen. In this study, males caught in spring, had higher lumen-to-tubule ratios than females $p<0.05)$. At the end of the spring period (May), females present the larger amount of lipid droplets per tubule and this may demonstrate that the intensive feeding period of the females has started. The similarity in the lumento-tubule ratio between males and females on March appeared to be expected because there is a positive effect on the benthic food web of the Pagasitikos Gulf at this time of year (Petihakis et al., 2005). Furthermore, the females of the May sampling exhibited similar lumen-to-tubule ratios compared to the females of the March sampling. However, for the male individuals, the lumen-to-tubule ratios of those caught in May appeared to be significantly bigger than the ratios of those caught in March $(p<0.05)$.

The females caught in May had significantly smaller Fcell-to-tubule ratios than all the other individuals (Table 2). F-cells are mainly responsible for the release of digestive enzymes into the lumen of the digestive gland. Digestive enzymes are secreted into the foregut for extracellular digestion (Brunet et al., 1994). A small F-cell-to-tubule ratio indicates that there was a long starvation period or that the 
individual was sampled at the end of its digestive cycle. Additionally, under short-term food deprivation, the F-cell numbers and enzyme production can increase to replenish gastric fluid in preparation for the next meal (Simon, 2009).

In our results, the F-cell numbers per tubule for $N$. norvegicus for females sampled on March and May and males sampled on March and May were similar (Table 3), which indicated that there was adequate food consumption for Nephrops. Karapanagiotidis et al. (2015) measured a 0.20 and 0.17 lumen-to-tubule area in $N$. norvegicus fed mussels or pellets for 20 days. $N$. norvegicus that had been starved for a long period had a 0.27 lumen-to-tubule area (Kroupis, 2010). Comparing the lumen-to-tubule areas of both samplings for males and females with the estimated results by Kroupis (2010), our results are smaller, thus indicating no starvation. In both groups of Nephrops fed the mussels and pellet diets, the F-cell-to-tubule ratio was 0.05 . In this study, the individuals had a short-term food deprivation since they remained two days in the traps at the March and at the May sampling, thus bigger F-cell-to-tubule ratio were observed than those reported in Kroupis' (2010).

The B-cell-to-tubule area ratios did not differ among months or sex $(p>0.05)$. B-cells are related to the elimination of residual indigestible products, so a high B-cell-to-whole tubule area ratio may suggest that the consumed feed was poorly digested (Simon and Jeffs, 2008). Our measurements are smaller than those of Karapanagiotidis et al. (2015) for the pellet diet (0.13) and bigger than those of the mussel diet (0.06), which indicated that the food our $N$. norvegicus individuals consumed was neither poor nor optimal. The similar number of B-cells per tubule of between males and females at the March sampling may indicate similar food digestibility. A high number of B-cells per tubule is a likely indicator of excessive intracellular digestion and/or the elimination of waste products (e.g., toxic mineral elements, digestive enzymes, undigested particles) from the digestive gland (Simon, 2009). Juvenile Jasus edwardsii lobsters fed a formulated diet showed an increased number of B-cells per tubule at $18 \mathrm{~h}$ after feeding, suggesting poor digestibility (Simon, 2009). Twenty-four hours after feeding, the number of B-cells per tubule was almost halved (Simon, 2009).

The similar digestive condition of individuals of different sexes was evidenced by the similarities found in their R-cellto-tubule area. R-cells of $N$. norvegicus of the May sampling (both males and females) have a larger density of lipid droplets, suggesting that $N$. norvegicus from the March sampling were in poorer nutritional and digestive conditions. Simon (2009) reported that lobsters fed a formulated diet had a lower level of lipid droplet accumulation in their R-cells. It is likely that R-cell area is directly related to the amount of stored nutrients in lipid vacuoles and/or glycogen granules (Berillis et al., 2013). Lipid droplets are intracellular organelles and cytoplasmic structures that are responsible for lipid storage and mobilization (Murphy et al., 2009). Abundant lipid inclusions represent the primary storage material of R-cells, although small particles of glycogen are also present in the cytoplasm (Barker and Gibson, 1977). The observed differences in hepatopancreatic lipid concentrations may depend on the food capacity and consumption (Mente, 2010).

The availability of food and an animal's sex are two important variables that affect the nutritional status of
$N$. norvegicus. The seasonal histomorphological variability found between Nephrops male and female stocks in the Pagasitikos Gulf is likely the combined effect of site-specific environmental factors such as sediment type, water circulation and temperature and biological factors such as density and food availability, which changes seasonally. Nevertheless, the findings of this study could be used to show whether the females have an increased nutritional status that reflects their access to food over a specific month or increased food availability in a specific month and whether this status is different from males that continue to forage on the sediment surface for food over the same period. Thus, this study validated the use of digestive gland as a useful indicator of nutritional condition in Nephrops and evaluated a specific image analysis algorithm as a potential tool for measuring the species nutritional condition. Digestive gland can be used as an indicator for assessing the nutritional status of Nephrops stocks to propose a locally seasonal fishery management scheme for the sustainability of the wild stocks. The approach has also significant potential for research transferable to other crustacean species.

\section{References}

Baden SP, Depledge MH, Hagerman L. 1994. Glycogen depletion and altered copper and manganese handling in Nephrops norvegicus following starvation and exposure to hypoxia. Mar Ecol Prog Ser 103: 65-72.

Barker PL, Gibson R. 1977. Observations on the feeding mechanism structure of the gut and digestive physiology of the European lobster Homarus gammarus (L.) (Decapoda: Nephropidae). Mar Biol 26: 297-324.

Bell MC, Redant F, Tuck I. 2006. Nephrops species. In: Phillips BF, ed. Lobsters: biology, management, aquaculture and fisheries. Oxford: Wiley-Blackwell, pp. 412-462.

Berillis P, Simon C, Mente E, Sofos F, Karapanagiotidis IT. 2013. A novel image processing method to determine the nutritional condition of lobsters. Micron 45: 140-144.

Brunet M, Arnaud J, Mazza J. 1994. Gut structure and digestive cellular processes in marine Crustacea. Oceanogr Mar Biol: Annu Rev 32: 335-367.

Conklin DE. 1995. Digestive physiology and nutrition. In: Factor JR, ed. Biology of the lobster Homarus americanus. London: Academic Press, pp. 395-445.

Dall W. 1981. Lipid absorption and utilization in the Norwegian lobster, Nephrops norvegicus (L.). J Exp Mar Biol Ecol 50: 33-45.

dos Santos A, Peliz A. 2005. The occurrence of Norway lobster (Nephrops norvegicus) larvae off the Portuguese coast. J Mar Biol Assoc UK 85: 937-941.

Factor JD. 1995. The digestive system. In: Factor JR, ed. Biology of the lobster Homarus americanus. London: Academic Press, pp. 390-343.

Froglia C, Gramitto ME. 1979. An estimate of the fecundity of the Norway lobster (Nephrops norvegicus) in the Adriatic Sea. Rapp Comm Int Mer Medit 25/26: 227-229.

Gibson R. 1983. Feeding and digestion in decapod crustaceans. In: Pruder G, Langdon CJ, Conklin DE, eds. Proceedings of the Second International Conference on Aquaculture Nutrition: Biochemical and Physiological Approaches to Shellfish Nutrition, Baton Rouge, Louisiana State University, pp. 59-70.

Gibson R, Barker PL. 1979. The decapod hepatopancreas. Mar Biol 17: 285-346.

Hellenic Statistical Authority. http://www.statistics.gr/en/home/. 
Hirsch GC, Jacobs W. 1930. Der Arbeitsrhvthmus der Mitteldarmdruse von Astacus leptodactylus. II. Teil: Waschstum als primarer Factor des Rhythmus eines polyphasichen organigen Sekretionssystems. Z Vergl Physiol 12: 524-557.

Jones PL, Obst JH. 2000. Effects of starvation and subsequent refeeding on the size and nutrient content of the hepatopancreas of Cherax destructor (Decapoda: Parastacidae). J Crustac Biol 20: 431-441.

Karapanagiotidis IT, Mente E, Berillis P, Rotllant G. 2015. Measurement of the feed consumption of Nephrops norvegicus feeding on different diets and its effect on body nutrient composition and digestive gland histology. J Crustac Biol 35: 11-19.

Kormas KA, Karayanni H, Christaki U, Giannakourou A, Assimakopoulou G, Gotsis-Skretas O. 2014. Microbial food web structure and its impact on primary production in a mesoOligotrophic coastal area (Pagasitikos Gulf, Aegean Sea). Turk $J$ Fish Aquat Sci 14: 527-537.

Kroupis K. 2010. The effect of starvation and different diets (natural and artificial food) on the histology of Nephrops norvegicus digestive gland, Volos. Dissertation.

Mente E. 2010. Survival, food consumption and growth of Norway lobster (Nephrops norvegicus) kept in laboratory conditions. Integr Zool 5: 256-263.

Mente E, Carter CG, Barnes RS, Karapanagiotidis IT. 2011. Protein synthesis in wild-caught Norway lobster (Nephrops norvegicus L.). J Exp Mar Biol Ecol 409: 208-214.

Mente E, Karapanagiotidis IT, Logothetis P, et al. 2009. The reproductive cycle of Norway lobster. J Zool 278: 324-332.

Moutopoulos DK, Stergiou KI. 2012. Spatial disentangling of Greek commercial fisheries landings by gear between 1928-2007. J Biol Res 18: 265-279.

Murphy S, Martin S, Parton RG. 2009. Lipid droplet-organelle interactions; sharing the fats. Biochim Biophys Acta 1791: 441-447.

Petihakis G, Triantafyllou G, Pollani A, Koliou A, Theodorou A. 2005. Field data analysis and application of a complex water column biogeochemical model in different areas of a semienclosed basin: towards the development of an ecosystem management tool. Mar Environ Res 59: 493-518.

Ridgway ID, Taylor AC, Atkinson RJA, et al. 2006. Morbidity and mortality in Norway lobsters, Nephrops norvegicus: physiological, immunological and pathological effects of aerial exposure. $J$ Exp Mar Biol Ecol 328: 251-264.

Rotllant G, Anger K, Durfort M, Sarda F. 2004. Elemental and biochemical composition of Nephrops norvegicus (Linnaeus
1758) larvae from the Mediterranean and Irish Seas. Helgol Mar Res 58: 206-210.

Rotllant G, Charmantier-Daures M, Charmantier G, Anger K, Sarda F. 2001. Effects of diet on Nephrops norvegicus (L.) larval and postlarval development, growth, and elemental composition. $J$ Shellfish Res 20: 347-352.

Rotllant G, Gisbert E, Karapanagiotidis IT, Gkolomazou E, Mente E. 2014. Effects of different diets on the digestive physiology of Norway lobster Nephrops norvegicus. J Shellfish Res 33: 1-9.

Sarda F. 1995. A review (1967-1990) of some aspects of the life history of Nephrops norvegicus. In: Aiken DE, et al., eds. ICES Marine Science Symposia, Copenhagen, Denmark: International Council for the Exploration of the Sea, pp. 78-88.

Simon CJ. 2009. Digestive enzyme response to natural and formulated diets in cultured juvenile spiny lobster Jasus edwardsii. Aquaculture 294: 271-281.

Simon CJ, Jeffs A. 2008. Feeding and gut evacuation of cultured juvenile spiny lobsters Jasus edwardsii. Aquaculture 280: 211-219.

Smith C, Marrs SJ, James R, et al. 2003. Underwater television for fisheries-independent stock assessment of Nephrops norvegicus from the Aegean (eastern Mediterranean) Sea. Mar Ecol Prog Ser 256: 161-170.

Smith CJ, Papadopoulou KN. 2008. The crustacean Nephrops norvegicus: growth and reproduction behaviour. In: Mente E, ed. Reproductive biology of crustaceans. Case studies of decapod crustaceans. Enfield: Science Publishers, pp. 491-507.

Stentiford GD, Chang ES, Chang SA, Neil DM. 2001. Carbohydrate dynamics and the crustacean hyperglycaemic hormone $(\mathrm{CHH})$ : effects of parasitic infection in Norway lobsters (Nephrops norvegicus). Gen Comp Endocrinol 121: 13-22.

Ungfors A, Bell E, Johnson ML, et al. 2013. Nephrops fisheries in European waters. Adv Mar Biol 64: 247-314.

Watts AJR, McGill RAR, Albalat A, Neil DM. 2014. Biophysical and biochemical changes occur in Nephrops norvegicus during starvation. J Exp Mar Biol Ecol 457: 81-89.

Welden NA, Taylor AC, Cowie PR. 2015. Growth and gut morphology of the lobster Nephrops norvegicus. J Crustac Biol 35: 20-25.

Yonge CM. 1924. Studies on the comparative physiology of digestion. II. The mechanism of feeding, digestion and assimilation in Nephrops norvegicus. J Exp Biol 1: 343-389.

Zar JH. 1996. Biostatistical analysis, 3rd ed. New Jersey: Practice Hall.

Cite this article as: Stathopoulou E, Apostologamvrou C, Vafidis D, Mente E, Berillis P. 2017. Sex differentiation in the histology of the digestive gland of Nephrops norvegicus from Pagasitikos Gulf during spring. Aquat. Living Resour. 30: 28 